\title{
Being Outsider inside the Outside
}

\author{
Yakup Yasar \\ Assist. Prof. Dr., Department of English Language and Literature, Karamanoglu Mehmetbey University, Turkey
}

Copyright $@ 2019$ by authors, all rights reserved. Authors agree that this article remains permanently open access under the terms of the Creative Commons Attribution License 4.0 International License

\begin{abstract}
The article is based on two important questions concerning the act of migration and the troubles the immigrants encounter after World War II: how can migrating from hometown/ native country to another place be examined under the circumstances of civilization? How the problems of identity, assimilation, integrity, hybridism and hopelessness can be explained within the impacts of migration or Diaspora? The study focuses on the paradoxical word civilization itself and the victims of the civilized hunters. It includes the memories told by the immigrants themselves, the interviews made with them and social analysis done by the Professional sociologists and psychologists so as to justify the thesis statement; Adapting to a new and different culture is so difficult that people encounter various troubles during getting accustomed there. The consequences of migration incorporating children in particular within the frame of generational conflicts and contradictions are emphasized as well. Additionally the study presents the family life of the couples having hybrid children and expresses the seriousness of the troubles faced after migration. Finally, each essential point described above is so significant that they justify the argumentation based on "being outsider inside the outside" is to say "becoming the slave of the freedom which is valid just for the natives".
\end{abstract}

Keywords Migration, Diaspora, World War, Children, Identity Problem, Civilization, Outsider

\section{Introduction}

Concerning the 40 million people killed in the war and the people influenced by it and had to move to another place I get perplexed in deciding either the former or the latter are unfortunate. The disgusting hornet's nest would widespread all around the world and damage the people with its poison including Diaspora/ migration, discrimination, isolation, assimilation, and racism. "The Big Four- Imperialism, Industrialism, Capitalism and Nationalism-" [1] played the biggest role in it. "The Big Four" is supported by Civilization. People from the countries of the third world began to migrate to or got forced to migrate- Diaspora- to the civilized countries. For them civilization seemed something marvelous, incredibly wonderful and full of luxury. They did not account the consequences of this painful journey full of mystery.

This is something I have been thinking on. It is explicitly a great problem for me, but I have not solved it yet. Maybe "it is not a problem but a given" [1]; it is civilization. If civilization means killing people, mocking the poor, looking down on the others, having vanity, being racist, and having an ideology to 'make the rich richer by causing the poor poorer', I definitely do not desire to get civilized. I do not want to fall in that inferior condition. This is my idea may be the civilized or the people thinking themselves civilized or imitate to seem so, dissent from me. People always say "Civilization is an enormous ocean.” Indeed I agree on this in a way, yet the sentence is incomplete. The whole should be 'civilization is a great ocean without water (like a desert).' I have experienced it. My family migrated from the east- Agri, which is my hometown- to the westIzmir- of Turkey. I have lived for 25 years in Izmir. I am ethnically Kurd, I have had a friend who has offended me with screaming

Don't say you are from Turkey, since you are not European you are not civilized but a primitive boy. I don't want to stay at the same place where you exist, go away. Define yourself as if you are/were Iraqi, Iranian, Syrian, as you are similar to them. I am embarrassed with my identity when you say you are a Turk since I am quite a Turkish girl as well.

I really experienced this event. When I read this, I do not even believe these sentences but obviously I have encountered such perfectly civilized person (!) who scorns people around her - I am one of them- and sees herself as if she were a civilized person from any other European country rather than ours although she has been living in Turkey since she was born. Her attitude may be called as a national discrimination, which is caused by the differences among the cities of Turkey.

\section{Discussion}

What is more, to talk about the international migration, 
the immigrants in their new place encounter "urged by a variety of motives there they came. Everything has tended to regenerate them. New law, a new mode of living a new social system."[2]. They have troubles to get accustomed to the new law, since it is obviously different from the law of their native land. The treatment accepted and not sentenced with bitter punishment might be judged in just the opposite way. For instance, my aunt and her family have been living in Germany for years. I went to visit them nearly ten years ago in Pasqua. During my visit I witnessed some events about the law of Germany which seemed interesting to me. we do not have such items in our law: People who have their own pets, dogs in particular, have to pay tax; The ones using their mobile phone while driving a car are punished to pay fit by the traffic police; The citizens are free to live according to their religious values and so on. When I asked them whether they could have got used to them, their common answer was tragic-comic "Everything is OK! But dogs have more rights than us. We have the perplexity of either we are the animals or human beings. Being human is less precious than being an animal.” In fact, being human is more respectable than being the latter if you are the native citizen of the country but the immigrant.

In addition, for the new mode of living and a new social system, the immigrants are faced with the troubles related to language, religion, identity which are very significant essences of each nation and person. Simon Frith (1996), for instance, defines identity in connection with music as a kind of processual, subjective and collective experience of self-in-process:

My argument here, in short, rests on two premises: first, that identity is mobile, a process not a thing, a becoming not a being; second, that our experience of music - of music making and music listening - is best understood as an experience of this self-in-process. [3].

Indeed, identity is a huge frame incorporating everything that is part of the construction of it, such as language and religion in particular. Identity is questioned in the book Unrooted childhoods "How do we determine our identity? Which language do we choose for self-expression? And are we merely a collection of our cultural attributes, or can we select those we most want to keep?” [4], and is followed with "Language is the most portable cultural landmark. It facilitates communication, eases transitions, and connects new comers with existing social groups. It is through language that one forges identity." [4] It is explicitly true that language is a great power to have cultural intercourse and to become the member of the society. However, it is not so easy for the children of the immigrants that as growing up they have to learn two languages; the one spoken at their home and the other spoken in the society.

The family home preferred within the developmental state can be described as a "cocoon", a safe space in which the child is protected from the outside world. The family home could remain a space of 'innocence' and all within it could remain trivial, seen as dependent,

\section{infantile and innocent.” [5]}

Generally, parents try to use their mother tongue rather than the language of the country they have migrated to, so as to teach their children how to speak it, since they do not want to put their posterity in the danger of assimilation. At first they achieve this but then, when the children begin to go to school everything become more complicated and perplexing, since the children see that the language they have learned from their parents is useless at school and in the society. Henceforth, they have to learn a new language so that they can go on their education. Keeping both of the languages in mind is quite a big handicap for them. I talked with a Turkish child whose family migrated to Italy years ago. He was 12 years old and going to the $5^{\text {th }}$ class at the primary school. During our dialogue, I noticed that he used Italian words in some of his sentences he uttered in Turkish and I asked the reason why he was doing so he said

I do not know, and it happens unintentionally. This is the same at my school. While I am speaking in Italian at the class I mix some Turkish words with it and the teacher gets angry with me and rebukes me. This causes me to lose my self-confidence. I don't want to study my lessons. I can't keep two languages in my mind. I want to return to Turkey to continue my education there because at that time I will use the same language both at school and at home.

This is one of the examples that can be given for the miserable situation of the children of the immigrants. Additionally, those children cannot talk to their relativeswith this I mean the friends whose parents have migrated from the same country, as these people are as if they were relatives of each other in the society which they are alienated from- in their mother tongue. In the article titled "Dynamics of Inclusion and Exclusion in a Newly Multi-ethnic Irish Primary School” written by the scholar Mary Kelly and Dympna Devine, there are parts including the interviews made with the children of migrated families. There is an Arabic child says

People are different. When I speak my language, Arabic, people go: 'What the heck you are saying?'. 'You don't have to know, I'm speaking to my sister' and they go 'I'm telling the teacher on you.' They think I am saying something about them, but I'm not. [6].

There remains two ways for her either to speak their language or to get isolated. If she wants to have lots of friends, she can keep contact with, she has to choose the former way because, in his book The Pleasures of Academe: A Celebration / Defense of Higher Education, Axtel James quoted from Carlos Fuentes -from the migrant family in America- that "No culture... retains its identity in isolation; identity is attained in contact, in contrast, in break through." [12]. Hence, if just one option stands before the children like the Arabic one what is waiting for them?

What is more, Clothing is another significant criterion, which resembles identity. As Waerdahl says 
Personal ability and capacities, alienation from present inference group and knowledge of norms and values of the group one aspires to become a member of. Clothes are used as the primary element of discussion, because dressing is one way to signal group belonging personal status and personal qualities and abilities. [7].

I have a friend whose family migrated from the eastern part of Turkey to the western approximately 23 years ago. In the first few years of their inhabitance in Aliaga, which is a county of Izmir, he would be wearing his traditional clothes which he had worn in his previous town or hometown. As time passing, he has extended his peer groups and with this, he has changed his dressing style well then he has been wearing the clothes like his friends around him. According to psychological and sociological analysis, he must try to be recognized in the group to prove that he is one of them and should not be otherwise. Indeed, he might have fear of getting despised by others who may see and treat him as 'the other'. In fact, even though he can achieve this or he thinks he has overcome the fear within the western dressing, it is definitely obvious that he is not identically western but eastern, since his color, dialect and behaviors explicitly belong to the eastern culture or tradition. This is a similar problematic situation for the people who have migrated abroad. In relation to fashion and clothing there is evidence that some children may feel 'left out' if they do not have the right products. Social class, gender and ethnicity are likely to interest them in important ways. Again, I have a friend from Turkey, she is actually living in the west of Turkey and was born there. Because of geographical condition we are neither European nor Asian we are like a bridge in the middle. She looks down on the Asian people and thinks them primitive and she tries to be accepted and called as a European girl. She has been trying to do so with the expensive, fashionable clothes of the European style she has bought to dress (on). Actually, with her clothes and hairstyle, she seems obviously a European person. However, there is still a big gap between her and the original Europeans. This gap cannot be abolished with the Turkish language unfortunately. There is a Turkish proverb for this situation: "A golden packsaddle is put on the donkey yet it is still a donkey." I do not mean that we as the Turks are donkeys but the reality always exists no matter what we try to do. It is the same for an English, German, Irish, Italian, or American, we cannot make a German an Italian, an Irish an English, an American a Turk. Although "Americanization" has been the policy of America for years they could not have changed the color of $100 \%$ of the people living there or in another country under the dominance of America. For example J. Hector St. John de Crevecoeur mentions the immigrants in America in his article (letter III ) “What is an American”, there he says "British America" [8] which shows the mixed identity and characteristics of the immigrants. Still they have their national characteristics and are not assimilated wholly. Thus, no matter how the immigrants are forced to get assimilated, no one can be completely isolated from his/her own identity. Therefore assimilation may be defined as a process of making the victim- the one assimilated- delude himself/ herself with a new identity which does not belong to him/her in reality. That is to say, assimilation is self-delusion, because nobody can obliterate the past. They may forget but they cannot make it never happened.

On the other hand, Waerdahl mentions in her article that according to social analysis done by the professional sociologists and psychologists "Clothes and material possessions must be regarded as tools by which social identity is negotiated, tested out and developed." [7]. This demonstrates how the children or adolescents -like the two of my friends mentioned previously- end up in dilemma and perplexity of identity. My sister is one of them who have the social identity problem. One day I asked her why she was wearing the clothes our parents did not permit due to our tradition. She replied that "Because my friends are wearing such clothes.” This was the only reason that made her live according to the exterior impression which otherwise would also tempt her to get outsider. I know her character very well the dressing style she has chosen is definitely not her preference. She behaves according to the others who may blacklisted her as "the other" and may look down on her if she does not do so. Has she been successful? I am not sure; the only thing I am certain about is that she is not happy with her decision which is decided by the exterior influence but her. The scholar Randi Waerdahl has examined professionally psychology of the immigrant children who have been trying to hide their own identity behind the clothes worn by the peers around. The following excerpt is from the interview Mr. Waerdahl has done with the girl Heidi:

Randi: What clothes and such, does that mean anything at this school? I mean what kind of clothes you wear; could that influence your popularity or something?

Heidi: A little, maybe just a little.

Randi: It means a little, how do you mean...?

Heidi: Well nobody gets teased for not wearing Levi's jeans or anything, nobody teases them or anything. Well they are sort of expensive. They are quite expensive in fact.

Randi: Well if you want a pair of Levi's so badly; would you consider spending your savings and buying them for yourself?

Heidi: Yes. Or maybe not. I don't want it that much right now. But I am sure I would have taken a pair of Levi's if I have them given it to me, if I had a choice.

Randi: But why Levi's?

Heidi: Well yes. I like them, and they are very comfortable, really. [7]

Then Waerdahl goes on to claim The social function of a pair of Levi's is that it reduces risk, allowing Heidi to hide herself among the rest and to avoid being the object of teasing... Since "everyone wears them”, a pair of Levi's might function as a social 
camouflage...Heidi gives functional reasons for her choice and says they are comfortable and 'good to wear' perhaps to mask her social anxiety [7].

There are a lot of types of Heidi, such as my sister and my friends, in the countries where their families migrated or had to migrate, and those children try to satisfy themselves with wearing the similar clothes like the peers/ people in their surroundings to hide their own identity but they fail in doing so due to their mother tongue and their dialect. In the book "Unrooted Childhoods" Faith Eidse and Nina Sichel, the editors of the book, mention that for Peter Ruppert, one of the children whose families had migrated to America, whose childhood was covered by war and displacement, identity is forged in personal memory and the language:

Born in Hungary just before the invasion of the Nazis, he was shuttled from one refugee camp to another, suffering family separation and reunion, sorrow and silence. By the age of ten, when he was finally relocated to the United States, he had lived in six countries and learned four languages. He attributes a lifelong problem with stuttering to the near-constant postwar displacement and to the many languages and identities he had to acquire. [4].

Remembering the painful past, he must define himself who he is. The new life after the migration requires learning a different language yet every language learned "maps world differently; each construes time and space and memory in different ways." [4] Who, then is he? And where does he belong to? Struggling to get rid of his accent "that makes it impossible to forget your past” and your real identity, he considers language as "the barbed wire of the global community” [4] and himself as an outsider. His parents emphasized learning new languages as a way to fit in, to forget the past, and to adopt a new identity, but his accent and his stutter forever marked him as an outsider. Peter Ruppert is an epitome of immigrants who could not have got adjusted to the new life and integrated to the new world in a way.

What is more, as mentioned previously identity contains religion as well. In their new place the immigrants also face with religious problems. Even the Christians are in contradiction with the Christianity common in the country they have migrated to, as the belief is taken approximately differently by each nation. There are religious sects such as Catholicism, Puritanism, Orthodox, Evangelicalism (Protestantism) and so on. For example, a puritan person must have conflicts and troubles in the country where Catholicism is essentially believed in. This is similar for the situation of the Hebrews. However, for the Muslims the ratio of the peril for their religion is higher when they migrate to non-Muslim country. As it is known Islam and the other religions are strictly divertive and a conservative Muslim obviously end up in a catastrophe when he/she migrates to a non-Muslim country. "Muslims in the
Diaspora experience a range of practical, psychological and pragmatic difficulties including the problems of establishing enduring relationships with the opposite sex, of contracting acceptable marriages, and of adapting religion to a new life." [8]

To tell the truth, I think the immigrations after the World War II is obviously a Diaspora no matter what the reason is, since nobody wanted to leave their hometown voluntarily so as to struggle on adjusting to a new life, a new law, a new society, a new religion and everything waiting for them in a new country. In general, one of the essential reasons behind the migration which I call Diaspora is the financial insufficiency. Poverty metaphorically is a great power that causes Diaspora even though it means being potentless and miserable. As Handlin says "Peasants learned that poverty was a dog whose teeth sank deep.” [9] When I was in Italy in 2007, one day I interviewed with a Turkish man whose name was Seidi. He was one of the immigrants in Modena. He was nearly 30 years old;

Yakup : When did you migrate here and why?

Seidi : I came here 5 years ago because of the economic reasons. I got married after the compulsory military service and I had to provide my family. Then we had a baby when he was 1-year-old I migrated to Italy within an illegal way. I hoped to get the residence permit but still I couldn't have got it. Due to this neither can I bring my wife and my son nor I can go there.

Yakup : This must be very troublesome for you.

Seidi : Of course. Now my son is 6 years old and he has begun the school. I missed them very much. When I think my wife and son I feel bitterly pain in my heart since I have to be with them they need me (He was bound to cry). I don't know what to do. I haven't been able to get integrated here. I have lost the characteristics of my identity, my religious values in particular. I can't go everywhere and apply for work because of my illegal situation. I went a few places to work and they paid me less than I deserved since they knew my situation. I am afraid to talk to the Italian citizens. I am living in isolation. If I don't get the residence permit, I will return to Turkey in about 4 months.

Yakup : Why have you waited for 5 years?

Seidi : I have had hope for the residence permit but I don't have energy now and my psychology is not so good. I am like in a prison in which I have lost my freedom and Islamic values...

During our dialogue I was looking into his eyes, indeed everything was clear through them which were looking for a hand to take him from the prison holding many other immigrants- so called prisoners- too. What makes the immigrants go on living there, is just 'the hope' though it is in hopelessness. If they attempt to go back they will live immigrant life again. As with the passing of time a lot of things must have changed in their ex-hometown as well. Besides, some of the people migrate so that they may have a chance to have better education. Additionally, it is argued 
that "surprisingly perhaps, the desire for secular education continues to have important religious dimensions, even when this education is sought in a non-Muslim country and even when they are confronted by ways of living which directly contradict them.” [8]. Apparently Seidi left his country willingly to make ends meet and support his family, yet in reality it was just the poverty forcing him into Diaspora which has only one door opening to the prison.

Moreover, not only the immigrants but also their children are faced with difficulties in their life. They generally choose atheism instead of being in dilemma between two different religions. For example; in the article "Dynamics of Inclusion and Exclusion in Children's Social World in School" which is in the book Education in Ireland: Challenge and Change, there is an interview done with Patrick one of the children in the hazard of suffering religious complexity;

Patrick: I wouldn't like to be a Muslim in any school. Interviewer: Why?

Patrick: I just don't want to get picked on by anybody. I wouldn't like to be a Protestant either. [10]

However, in addition to this there are such children who try to live according to the religious values taught them by their parents and have chosen the way to contend with the negative treatments in their surroundings.

Salma: I remember that one day I went with my scarf after my religion class. They were asking me questions but I really didn't mind about it... for them to know more about Islam.

Interviewer: And how did you feel about it Salma?

Salma: I feel embarrassed in front of everybody. They

say like you are small and you have to wear that scarf. [10]

Moreover, the consequences of the migration are distinctive when an immigrant gets married to a native citizen of the country he/she has moved to. The couple have hybrid children who have bi-identity and can form their life in any case according to either their father's or mother's identity. They are both posterities of the immigrant and the native citizen at the same time; therefore, they are neither "outsider" nor "insider" or they are both former and the latter. These kinds of children are luckier than the ones of the couple both of whom are emigrants, because the hybrid are able to transform and change easier. They are bi-identical. They have an opportunity to apply both of the identities into their social life. However some of the hybrid children still are not successful at benefitting from the advantages of having two identities. Then, what happens to the hybrids who cannot use either of their identities? They find themselves in a huge emptiness. They cannot choose which way to follow. They are in perplexity of the contradictions of the identities. Accordingly, this results in psychological and physiological deceases such as depression, migraine, heart-attack, obesity, insanity, seeing hallucination, aggressiveness etc.
Moreover, it is fairly clear that, children are the victims of migration. It does not matter whether their parents are innocent or not. They are the ones who pay the price for their ancestors' act of leaving their hometown. In fact, this is the problem of all the nations in the World. The adults pick a war in which children are killed, even though they have no will and role in the war. Obviously it will not be wrong to say civilization which tends the civilized into the war in order to maintain its hegemony over the so-called uncivilized, is the monster of children and their future. Therefore it is quite relevant to describe civilization as an ocean without water. The fluid in that ocean is not water; it is the blood of the victims of civilization. The only way to solve this problem or to get rid of this monster is to establish justice and prosperous life all around the World. However, it seems too utopic to accomplish. Because both civilization and justice are the commodities of the rich. You see the rich dominate the justice; and the justice dominates the poor. Then the ones dominating it call themselves civilized and the ones who are dominated by it are called uncivilized. That is to say that the rulers of the justice are free to withhold the others' freedom. Indeed, people should learn and know that civilization and freedom cannot be created and gained by killing people, children in particular. Happiness cannot be constructed upon the tears of the others.

\section{Conclusions}

Taking everything into account "The immigrants could not impose their own ways upon society, but neither were they constrained to conform to those already established" [9]. In addition, as in his play As You Like It one of Shakespeare's character, Jaques, says "All the world's a stage,/ And all the men and women merely players;/ They have their exits and their entrances." [11] He is quite right. Since life is a theatre; world is a stage; and we are the players. We have a lot of roles in every scene, in each place. If we are able to act our role well, everything will be OK. Otherwise there will be many troubles waiting for us. Due to the fact that we are actors we should wear different costumes for each character in every scene of life but we should definitely try to change our language and dialect we have used for the previous role as well, otherwise we cannot be successful (!) The children trying to dress on the clothes the same as their friends are metaphorically the examples of this. They are the actors who have changed their costumes but failed in doing the same on their language and dialect. In the theatre there is no scene on the stage for those kinds of actors they are sentenced to be an Outsider. On the other hand, in my opinion World War III has begun due to the migrations having been done since World War II. It has not been done by killing people to diminish the population but by expanding the emigrants' population. This may take lots of years to reach the end. 
But there is a victory waiting for the immigrants if they do not get assimilated and achieve to go on their life within the boundary of integration. Certainly this is very difficult to do but not impossible to overcome. In the future, more or less, the victory in the World War III will be of the immigrants, as their population will outweigh the natives'.

\section{REFERENCES}

[1] Dowd, Douglas F. (2007) At the Cliff's Edge. Printed in USA: Student Edition.

[2] J. Hector St John de Crevecoeur (1904). Letters from an American Farmer. New York: Fox, Duffield \& Company.

[3] Frith, Simon (1996). "Music and Identity". Questions of Cultural Identity. Ed. Stuart Hall \& Paul Du Gay. New Yorkshire: CPI Group (UK).

[4] Eidse, Faith; Sichel Nina (2004). Unrooted Childhoods. Intercultural Press.

[5] Lee, Nick (2001). Childhood and Society: Growing up in an Age of Uncertainty. Maidenhead: Open University Press.

[6] Kally, Marry; Devine, Deympne (2006). “'I Just Don’t Want to Get Picked on by Anybody': Dynamics of Inclusion and Exclusion in a Newly Multi- Ethnic Irish Primary School”. Children \& Society. Vol. 20. Pp. 128- 139.

[7] Waerdahl, Randi (2005). "Child to Youth Trajectories and Anticipatory Socialization”. Norwey: University of Oslo.

[8] Akbar, S. Ahmed; Hastings, Donnan (1994). Islam Globalization and Post-modernity. London: 11 New Fetter Lane.

[9] Handlin, Oscar (1973). The Uprooted. 2. Edition; Enlarged Boston-Toronto: An Atlantic Monthly Press Book.

[10] Devine, Dympna. "Dynamics of Inclusion and Exclusion in Children's Social World in School”, Education in Ireland: Challenge and Change. Ed. Sheelagh Drudy, About Gill \& Macmillan.

[11] Shakespeare, William (2005). As You Like It. Webster's Thesaurus Edition. USA: Icon Classics.

[12] Axtel, James (1998). The Pleasures of Academe: A Celebration/ Defense of Higher Education. Lincoln and London: University of Nebraska Press. 